\section{Evaluating green supplier satisfaction}

\section{Evaluating green supplier satisfaction}

\author{
Chunguang Bai \\ School of Management and Economics, \\ University of Electronic Science and Technology of China, Chengdu, China, and \\ Ahmet Satir \\ John Molson School of Business, Concordia University, Montreal, Canada
}

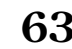

Received 12 February 2019 Revised 24 May 2019 20 October 2019 Accepted 6 November 2019

\begin{abstract}
Purpose - There is great uncertainty and volatility in the evaluation and measurement of green supplier satisfaction. The purpose of this paper is to fill this gap based on the information entropy theory (IET) to describe the probability of green supplier satisfaction degree.

Design/methodology/approach - The authors introduce a formal model using analytic hierarchy process (AHP), IET and entropy technique for order preference by similarity to an ideal solution (TOPSIS) method to evaluate green supplier satisfaction and promote them for the better implementation of green supply chain management practices.

Findings - The first finding is developing an effective framework for green supplier satisfaction, incorporating various measures of environmental dimension. Second, a hybrid uncertainty decision method is introduced, by integrating AHP and IET and entropy-TOPSIS.

Research limitations/implications - One of the main limitations of the research is that the authors introduced a conceptual example. Real-world applications need to investigate the accuracy and effectiveness of these measures, and the operational feasibility of this method.

Originality/value - This is one of the first works to provide a comprehensive appraisal model for evaluation of green supplier satisfaction. This study and research method can form general guidelines, and organizations can increasingly benefit from using green supplier satisfaction evaluation as a management tool. Green supplier satisfaction evaluation is just the beginning.
\end{abstract}

Keywords AHP, TOPSIS, Measures, Green supplier satisfaction, Information entropy theory

Paper type Research paper

\section{Introduction}

Academics and practitioners have long recognized that suppliers play a fundamental role in organizational strategic and competitive advantage, especially in the green supply chain management (GSCM) context (Bai and Sarkis, 2019; Govindan et al., 2015). As a diverse set of research shows, suppliers and buyers cooperate and integrate in close partnerships in order to mutually benefit from technical, economic and environmental advantages (Zhang et al., 2016; Li et al., 2016). One of the prominent drivers of this relationship is green supplier satisfaction. Green supplier satisfaction refers as a supplier's feeling of fairness with regard to buyer's incentives and feedbacks and supplier's contributions within a green buyer-seller relationship (Essig and Amann, 2009). Most buyers depend upon their suppliers to become more green and responsive. A buyer cannot expect to perform well if the suppliers are dissatisfied in their relationships with the buyer (Meena et al., 2012). Hence, satisfaction of suppliers on the economic and environmental dimensions is linked to the quality of the buyer-supplier relationship and to

(c) Chunguang Bai and Ahmet Satir. Published in Modern Supply Chain Research and Applications. Published by Emerald Publishing Limited. This article is published under the Creative Commons Attribution (CC BY 4.0) licence. Anyone may reproduce, distribute, translate and create derivative works of this article (for both commercial and non-commercial purposes), subject to full attribution to the original publication and authors. The full terms of this licence may be seen at http://creative commons.org/licences/by/4.0/legalcode

This work is supported by the National Natural Science Foundation of China Project (71772032, 71472031).

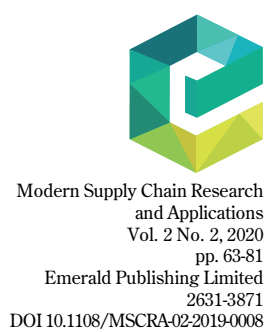


MSCRA

2,2

the degree of value creation between them (Vos et al., 2016). Although a number of articles are reported in the literature on evaluating suppliers' performance from the buyer perspective (Bai, Kusi-Sarpong, Badri Ahmadi and Sarkis, 2019; Bai and Sarkis, 2018), nowadays, buyers are focusing on building long-term and fair cooperation with their suppliers. Hence, it is essential for the buying firms to consider green supplier satisfaction in evaluating suppliers' performance.

In many business models, one finds that buyers have paid much attention to customer satisfaction and very little attention to supplier satisfaction (Saorín-Iborra and Cubillo, 2019; Saeidi et al., 2015). Few buyers conduct supplier satisfaction surveys and evaluation. If suppliers are dissatisfied, their overall performance may not be at the optimal level, which can, in turn, influence the buyer's green performance in procurement (Bai and Sarkis, 2010; Wong, 2000). Hence, investigating green supplier satisfaction and furthering their continuous improvement efforts is no longer a feel-good exercise, but is a necessity for buyers' success in fast changing business environment (Bai et al., 2017). Most buyers would benefit from a more formal approach to evaluate and establish sound green supplier relationships. However, research on green supplier satisfaction in GSCM is sparse and primarily of a conceptual nature (Dou et al., 2014). To effectively evaluate and improve green suppliers' satisfaction, a framework and an evaluation tool are needed. Such a tool should be part of a continuous improvement process in GSCM.

The biggest challenge in evaluating supplier satisfaction is the uncertainty and volatility associated with green supplier satisfaction. With the recent rise of green supply chain issues, green supplier satisfaction has become more complex and uncertain (Bai, Shi, Liu and Sarkis, 2019). Hence, this paper uses the information entropy theory (IET) to describe the probability of green supplier satisfaction degree that can reliably reflect and measure the uncertainty in green supplier satisfaction.

This study makes three major contributions. First, this is one of the first works to provide a conceptual understanding of green supplier satisfaction and a comprehensive appraisal model to evaluate it. The second contribution is in developing an effective framework for green supplier satisfaction, incorporating various measures from environmental perspective. Third, a hybrid uncertainty decision method is introduced, by integrating analytic hierarchy process (AHP) and IET and entropy technique for order preference by similarity to an ideal solution (TOPSIS). TOPSIS is a popular tool to evaluate a finite set of alternatives to find the best solution. However, it needs other methods to determine the weight of attributes. In order to overcome the limitations of single weight method, this paper uses the AHP and IET to determine the double weight of evaluating criteria in green supplier satisfaction evaluation. The subjective weight is decided by AHP and the objective weight is decided by IET. The biggest challenge is to deal with the high level of uncertainty in the measurement of green supplier satisfaction. This methodology provided in this paper fills this gap based on the IET to describe the probability of green supplier satisfaction degree.

The remainder of this paper is organized as follows. A literature review on green supplier satisfaction is provided in Section 2 with a summary of satisfaction measures proposed in the literature. A framework for green supplier satisfaction measures is presented in Section 3 based on the seven dimensions of the supplier satisfaction obtained from the literature review. We then introduce in Section 4 the fundamental concepts associated with AHP and IET and TOPSIS including advances related to information entropy distance analysis. Then, using an illustrative application example, we discuss the methodology developed in a step-by-step detailed process in Section 5. In Section 6, the findings of the sensitivity analysis are presented with some practical insights. Concluding remarks, limitations of the study and areas for future research are discussed in the last section. 


\section{Literature review on green supplier satisfaction}

Research on satisfaction emerged in the second half of the twentieth century (Cardozo, 1965). Scheer and Stern (1992) describe satisfaction as "the overall approval of and positive affect towards another party." In business relationship, the satisfaction was defined as "a positive affective state resulting from the appraisal of all aspects of a firm's working relationship with another company" (Anderson and Narus, 1984). The main focus of research on satisfaction is the operationalization of two constructs: human resource management-based employee satisfaction (Alegre et al., 2016) and marketing-based customer satisfaction (Blut et al., 2015).

There are a lot of literature on evaluating green suppliers, such as green supplier performance evaluation (Gunasekaran et al., 2010), green supplier selection evaluation (Bai, Kusi-Sarpong, Badri Ahmadi and Sarkis, 2019; Bai, Shi, Liu and Sarkis, 2019; Govindan et al., 2015), green supplier management practices evaluation (Kannan et al., 2014), green supplier development evaluation (Bai and Sarkis, 2019) and so on. However, most of these evaluations are from the perspective of the buyer, and seldom consider the satisfaction of the supplier. Therefore, the measures and methods used in these studies are not appropriate in dealing with the problem of green supplier satisfaction evaluation.

There are a number of studies in recent years that address supplier satisfaction in its broadest sense (Vos et al., 2016; Pulles et al., 2016; Praxmarer-Carus et al., 2013; Meena and Sarmah, 2012; Schiele et al., 2012; Mohanty and Gahan, 2011a, b; Ghijsen et al., 2010; Essig and Amann, 2009). Certain limitations of these studies open up avenues for further research. First, supplier satisfaction is defined and operationalized in various ways, but not associated with a commonly agreed definition and domain. Benton and Maloni (2005) define supplier satisfaction as "the feeling of equity with the relationship no matter what power imbalances exists" and call satisfaction the "overriding factor" in affecting the future of the buyer-supplier relationship. Essig and Amann (2009) define supplier satisfaction as a supplier's feeling of fairness with regard to buyer's incentives and supplier's contributions within an industrial buyer-seller relationship as these relate to the supplier's need fulfillment. Inspired by this definition, one can define "green supplier satisfaction" as supplier's feeling of fairness with regard to buyer's "green" incentives and supplier's green contributions within GSCM.

Second, only a few articles have made a clear reference to green supplier satisfaction. It is not conceivable to achieve a green supply chain without supplier support, which furnishes essential raw materials, components and other environmental inputs that affect green supply chain performance (Hollos et al., 2012). Therefore, buyers require to adopt a better collaborative approach to extend greening practices to suppliers to foster the degree of green supplier satisfaction.

Third, there is no study from GSCM context toward the development of a framework to measure the extent of green supplier satisfaction. There are some studies that develop a framework to measure supplier satisfaction, but green supplier satisfaction measures has been more or less neglected. Essig and Amann (2009) argue that one cannot maintain successful buyer-supplier relationships without measuring supplier satisfaction. In this paper, we make an attempt to develop a framework to measure green supplier satisfaction, which would impart knowledge regarding the current degree of green supplier satisfaction on various cooperation processes.

Fourth, few studies exist on how buyers can effectively evaluate supplier satisfaction, especially with respect to green practices. The extant literature for supplier evaluation methods refers to evaluating the buyers' satisfaction on suppliers' performance. The method of supplier satisfaction evaluation should measure suppliers' satisfaction, not buyers'. As purchasing managers begin to appreciate the possibilities of green supplier satisfaction, improvements in green supply chain cooperation are more likely to occur. Hence, buyers require measurement models and tools for evaluating green supplier satisfaction.

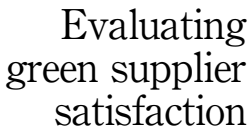

65 
MSCRA

2,2

66

This study aims to address the above limitations in the extant literature. First, based on the GSCM and supplier satisfaction, we offer a green supplier satisfaction measures framework that considers how GSCM process can contribute to green supplier satisfaction (Bai and Sarkis, 2014). Then, we develop a hybrid method to effectively evaluate green supplier satisfaction.

\section{A framework for green supplier satisfaction measures}

Studies on development of supplier satisfaction measures in the literature have been rather sparse. Mohanty and Gahan (2011a, b), Essig and Amann (2009), Benton and Maloni (2005), Maunu (2003), Wong (2000), Soetanto and Proverbs (2002) and Forker and Stannack (2000) examine supplier satisfaction and/or contractor satisfaction as a determinant of the quality of a business relationship. According to Maunu (2003), the longevity of the relationship, money, time, communication, quality, trust, commitment, innovation and flexibility are key elements of supplier satisfaction. Leenders et al. (2006) develop a purchaser-supplier satisfaction model with supplier satisfaction as one of its central components. Mohanty and Gahan (2011a, b) argue the following attributes to be influential in supplier satisfaction: trust, commitment, understanding, innovation, flexibility, communication, reputation, coercive and non-coercive power, cooperation, bonds, dependency, quality of service, mutual awareness, behavior of buyer and loyalty. Vos et al. (2016) focus on specific factors that have an impact on supplier satisfaction in terms of: access to contacts, growth potential, innovation potential, involvement, days to respond, length of relationship, operative excellence, preferential treatment, preferred status, profitability, relational behavior and reliability.

The current studies have no common agreement on the choice of supplier satisfaction measures and their corresponding indicators. For example, Benton and Maloni (2005) analyze only the degree of power asymmetry within industrial relationships as an influence on supplier satisfaction, while Gawantka (2007) identifies integrative as well as interactive aspects as key elements of contractor satisfaction. Various dimensions of supplier satisfaction obtained from the literature review are provided in Table I.

Based on our review of the literature and our previous research work (Bai et al., 2016; Bai and Sarkis, 2018), seven supplier satisfaction dimensions are identified as follows: green order management, green supply process, green supplier development, green communication, green cooperation, green conflict management and green commitment. The satisfaction measures identified for each of the seven dimensions are listed in Table II.

\subsection{Green order management}

Green order and contract management is key in relations involving environmental cooperation (Ghosh and Shah, 2015). Such a cooperation needs to be profitable for all stakeholders. This requires fair pricing and payment terms associated with environmental protection requirements. Also all parties need to follow the commonly agreed green rules and procedures (Varnäs et al., 2009). In this regard, client adherence to arrangements and long-term contracts as well as client payment habits, payment/receiving procedures and environmental requirements influences green supplier satisfaction (Blome et al., 2014; Wong, 2000).

\subsection{Green supply processes}

Common supply processes (such as ordering and delivery of goods) involve not only financial factors but also timing-related aspects, which directly affect supplier satisfaction (Maunu, 2003). Environmental factors, such as increased reputation, avoiding environmental fines and saving environmental pollution control costs, also need to be considered in evaluating green supply processes (Bai and Sarkis, 2018). Most importantly, green supply processes can help suppliers to maintain a stable long-term cooperative relationship with the buyers in the context of GSCM. 


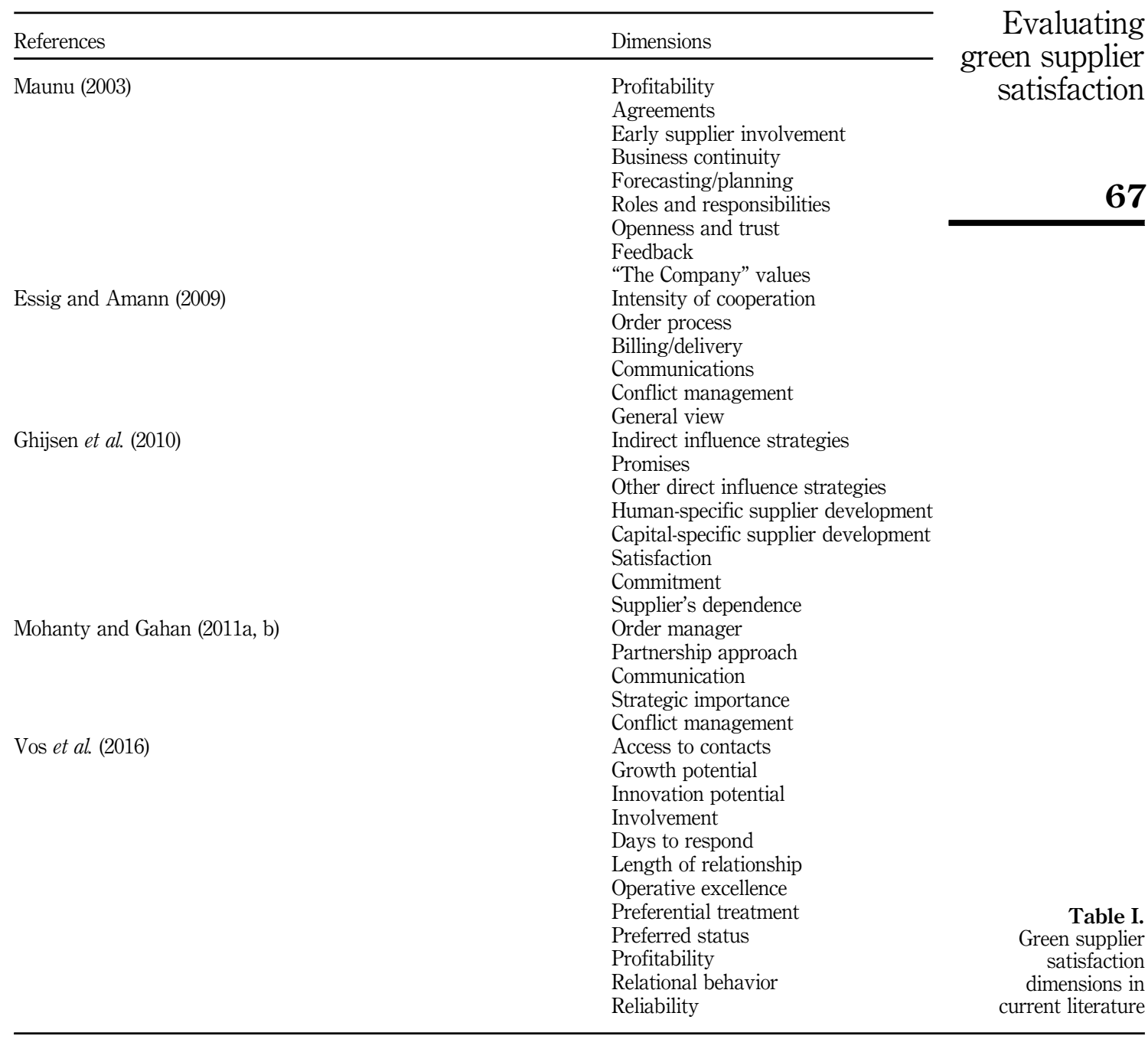

\subsection{Green supplier development}

Bai and Sarkis (2010) first grouped sustainable supplier development practices into three categories according to the resource type used in the practice: knowledge transfer and communication; investment and resource transfer; and management and organizational practices. Suppliers may not have the necessary resources and capabilities to meet a set of sustainable requirements by themselves. They need help, support and cooperation of buying firms (Fu et al., 2012). Green supplier development, as a strategically important initiative, results in suppliers being more environment friendly and more socially responsible (Rashidi and Saen, 2018).

\subsection{Green communication}

Communication is also identified as key element of supplier satisfaction that determines efficient interactions within a buyer-supplier relationship (Maunu, 2003; Gawantka, 2007). 
MSCRA

2,2
Dimensions

Green order management

\section{8}

Table II.

Green supplier satisfaction dimensions and measures

Green conflict

management
Measures

Range of green contracts

Environmental protection requirements

Clarity of environmental terms and conditions

Accommodative terms for environmental protection (if any)

Payment terms are fair about environmental issue

Green cooperation with the buyer is profitable

Adherence to payment terms about environmental issue

Allowing of green delivery period

Bargaining position during negotiations about environmental issue

Green supply process Transparency in green purchasing procedure

Environmental requirements in purchasing procedure

Structured and practical bargaining procedure

Guidance during first time green order processing

Compliance with environmental rules

Seamless, fluent, green logistics supply chain

Pay on time

Green supplier Provides supplier with equipment or tools for environmental improvement

development $\quad$ Provides supplier with knowledge or technology for environmental improvement

The buyer make financial and human resource investments for the supplier environmental issue

Provides supplier with environmental training/education

Provides supplier with capital for new environmental investments

Support from the buyer (introduction of new green technology, green logistics, green material)

Guidance from environmental quality control

Green communication Direct green communication, clear communication channel or medium

Frequency of communication on environmental issue

Quality of communication

Response time on environmental issue

Fair feedback on environmental issue

Green cooperation Trust, fairness in green relationship

Green cooperation developing together the vision and actions

Long-term green relationship

Better green cooperation, share green ideas and green technologies with customers

Collaborates with supplier in improvement and development GSCM activities for new raw materials and parts

Early supplier involvement in green design stage

Involvement in green decision-making process

Assurance of green orders

Openness between other green suppliers (price competitiveness)

Documented procedure for environmental conflict management

Availability of environmental conflict management cell

Attitude for environmental problem solving

Guidance to avoid environmental conflicting situation in future

Green commitment Offered an incentive for compliance with their environmental request

Promised supplier are ward for environmental cooperation

Green communication is likely to be considered a necessary green supply chain performance metrics. Lack of green communication can lead to several problems in GSCM, involving business, environmental and social responsibility issues (Bai and Sarkis, 2013).

\subsection{Green cooperation}

Skinner et al. (1992) report that satisfaction had a positive relationship with cooperation and a negative one with conflict. According to Ganesan (1994), satisfaction is a significant 
factor in achieving long-term cooperation relations. Without green supplier satisfaction, supply chain members are unable to generate the psychological factors such as trust, commitment and goodwill that are necessary for the partnership to be sustained (Hafezalkotob, 2017). Hence, there is a close association between green cooperation and green supplier satisfaction.

\subsection{Green conflict management}

The ability to manage green conflicts is considered to be a central element of beneficial supplier-buyer relationships (Benton and Maloni, 2005). The resolution of conflicts is mainly determined by the speed and quality of responses to environmental problems (Bai et al., 2016). The fair and timely resolution of conflicts plays an important role of green supplier satisfaction.

\subsection{Green commitment}

Green commitment is not only a driver of green supplier satisfaction; but also an indication of the longevity of the quality experienced in the buyer-supplier relationship (Benton and Maloni, 2005). Green commitment is defined here as a supplier's desire to maintain and strengthen the green performance, and provide a long-term orientation and vision to the relationship. Commitment is crucial in a relationship, as a committed supplier is much more likely to meet or even exceed the buyer's green needs (Davis et al., 2009).

\section{Background of the techniques used in the proposed methodology and notation}

There are four techniques used for the methodology developed to evaluate the green supplier satisfaction: AHP, information entropy weight (IEW), Kullback-Leibler (KL) divergence and TOPSIS. The fundamentals of the four techniques and the associated notation are presented in this section.

\subsection{Analytic hierarchy process (AHP)}

AHP, proposed by Saaty (1990), is a multi-attribute decision-making (MADM) model. Since this method has the advantages of structural integrity, simple theory and easy implementation, it is often used in situations where organizing and analyzing a complex decision problem involving multiple assessment criteria is involved (Scholl et al., 2005). The following steps for applying the AHP are provided in Saaty (1990):

- Step 1: model the decision problem as a hierarchy containing the decision goal, the objects and the criteria.

- Step 2: establish priorities among the objects (or criteria) of the hierarchy by making a set of judgments based on pairwise comparisons of the objects (or criteria).

- Step 3: synthesize these judgments to yield a set of overall weights for the objects (or criteria).

- Step 4: check the consistency of the judgments.

- Step 5: get a final decision based on the results of above processes.

\subsection{Information entropy theory (IET)-based weights}

Shannon first proposed the concept of information entropy in 1948 as the uncertainty of a stochastic event or metrics of information content and provided a scientific theory basis for modern information theory (Shannon, 1948; Cover and Thomas, 2012). Information entropy may be denoted by elimination of uncertainty, while the uncertainty of a stochastic source is described by a probability distribution. When the difference of the criterion value among the 
MSCRA

2,2

70

evaluating objects is higher and the entropy of the criterion is smaller, the criterion provides more useful information. Hence, the weight of this criterion should be set higher. On the other hand, if the difference is smaller and the entropy is higher, the relative weight of this criterion would be smaller.

This paper uses the AHP and IET to determine the double weight of the evaluating criteria in green supplier satisfaction evaluation. The subjective weight is to be determined by the AHP, while the objective weight is to be determined by the IET:

Definition 1. Suppose there are $n$ evaluating objects $\left\{x_{i} \mid i=1, \ldots, n\right\}$ and $m$ feature criteria $\left\{c_{j} j=1, \ldots, m\right\}$. For every pattern, the data matrix is constructed as follows:

$$
\begin{aligned}
\mathrm{X} & =\left(\begin{array}{cccc}
x_{11} & x_{12} & \cdots & x_{1 m} \\
x_{21} & x_{22} & \cdots & x_{2 m} \\
\ldots & \ldots & \cdots & \ldots \\
x_{n 1} & x_{n 2} & \cdots & x_{n m}
\end{array}\right)=\left(x_{1}, x_{1}, \ldots, x_{n}\right)^{\prime}, \\
& =\left(c_{1}, c_{2}, \ldots, c_{m}\right)
\end{aligned}
$$

where $x_{i j}$ is the measurement value of the $i$ th object and the $j$ th feature indicator.

Definition 2. For the $m$ criteria, $n$ evaluating objects evaluation problem, the entropy of $j$ th criterion is defined as:

$$
H_{j}=-k \sum_{i=1}^{n} p_{i j} \ln p_{i j}, j=1,2, \ldots, m,
$$

where $p_{i j}=\left(\left|x_{i j}\right| / n\right)$ is the rate of criterion value of the $j$ th criterion and the $i$ th object, $k=1 / \ln n,\left|x_{i j}\right|$ is the number of objects with the same criterion value of $i$ th object and suppose $\left(p_{i j}\right)^{*} \ln \left(p_{i j}\right)=0$ when $p_{i j}=0$.

Definition 3. The IEW of $j$ th criterion is defined as:

$$
w_{j}=\frac{1-H_{j}}{m-\sum_{j=1}^{m} H_{j}},
$$

where $0 \leqslant w_{j} \leqslant 1, \sum_{j=1}^{m} w_{j}=1$.

\subsection{Kullback-Leibler divergence}

In probability theory and information theory, the Kullback and Leibler (1951) divergence (information divergence, information gain or relative entropy) is perhaps the most frequently used information-theoretic "distance" measure. The KL divergence is a measure of how an object probability distribution is different from another object. It is used in many aspects of speech and image recognition.

Definition 4. If $x$ and $y$ are two probability distributions, the KL distance is defined as:

$$
D(x \| y)=\sum_{j=1}^{m}\left(x_{j} \log \frac{x_{j}}{y_{j}}\right),
$$

where $j$ is the probability space. 
In other words, $D(x \| y)$ it is the expectation of the logarithmic difference between two probabilities distributions $x$ and $y$. The divergence satisfies three properties, hereafter referred to as the divergence properties:

(1) self-similarity: $D(x \| x)=0$;

(2) self-identification: $D(x \| y)=0$ only if $x=y$; and

(3) positivity: $D(x \| y) \geqslant 0$ for all $x, y$.

In fact, $D(x \| y)$ is the distance from $x$ to $y$. Due to asymmetry, the distance from $y$ to $x, D(y \| x)$, is usually different. Despite this, the KL distance is geometrically important (Johnson and Sinanovic, 2001). Although the KL distance is not symmetrical, the so-called J-divergence is the average of the two possible KL distances between two probability distributions (Johnson and Sinanovic, 2001):

$$
J(x, y)=\frac{D(x \| y)+D(y \| x)}{2} .
$$

We use this symmetrical KL distance function to improve the TOPSIS method, which we call entropy-TOPSIS. The entropy-TOPSIS method can effectively measure the difference in the probability distributions of green supplier satisfaction.

\subsection{TOPSIS method}

TOPSIS method is presented in Chen and Hwang (1992). TOPSIS is an MADM technique to identify the solution from a finite set of alternatives. The basic principle is that the chosen alternative should have the shortest distance from the positive ideal solution and the farthest distance from the negative ideal solution. The TOPSIS steps are as follows:

- Step 1: calculate the normalized decision matrix.

- Step 2: calculate the weighted normalized decision matrix.

- Step 3: determine the positive ideal and negative ideal solution.

- Step 4: calculate the separation measures, using the symmetrizing KL distance.

- Step 5: calculate the relative closeness to the ideal solution.

\section{Green supplier satisfaction evaluation methodology, an illustrative example and managerial insights}

\subsection{Methodology and an illustrative example}

Given the background presented in the previous section on AHP, IET and TOPSIS characteristics and expressions, we now introduce a multi-step green supplier evaluation methodology within the context of an illustrative application. There are seven steps involved in this methodology. Details of the illustrative example are embedded in the steps defined below.

Step 1: construct the original decision system. For a database of green suppliers: decision system (table) is defined by $T=(U, C, V, \mathrm{f})$, where $U=\left\{S_{1}, S_{2}, \ldots, S_{n}\right\}$ is a set of $n$ suppliers called the universe. $C=\left\{c_{1}, c_{2}, \ldots, c_{m}\right\}$ is a set of $m$ attributes for the green supplier satisfaction. The $\mathrm{f}$ is a function used to define the values $V$. In this case $\mathrm{f}$ is $U \times A \rightarrow V$ the description function. For our illustrative case, $U=\left\{S_{i}, i=1,2, \ldots, 30\right\}$ (i.e. 30 suppliers) with seven measures of green supplier satisfaction $C=\left\{c_{j}, j=1,2, \ldots, 7\right\}$. We will assume seven sub-factors for each of the dimensions. These seven measures may be chosen from the numerous measures identified in Table II. 
MSCRA

2,2

72

Step 2: acquire the objective weight of each measure by AHP. This step is divided into three sub-steps.

Sub-Step 1: establish a matrix for paired comparison between measures. The decisionmaking team is to reach a final consensus after group discussions as to the application of standard scale values in matching pair comparisons. The values are to be assigned according to the AHP scale proposed by Saaty (1990). For our case, we get the final comparison matrix between measures shown in Table III.

Sub-Step 2: calculate the objective weights between measures. The objective weights $w_{j}^{o}$ between measures are obtained through the following equations:

$$
\begin{gathered}
c_{j k}^{*}=\frac{c_{j k}}{\sum_{j=1}^{m} c_{j k}}, k=1,2, \ldots, m, \\
w_{j}^{o}=\frac{\sum_{k=1}^{m} c_{j k}^{*}}{m} .
\end{gathered}
$$

For our case, we get the objective weights $w_{j}^{o}$ : 0.330, 0.113, 0.180, 0.087, 0.178, 0.056, 0.056.

Sub-Step 3: calculate the consistency rate (CR). The $\mathrm{CR}$ is derived from consistency index (CI) and random index (RI) through the following equations and Table III. When CR does not exceed 0.10, it achieves the satisfaction level:

$$
\begin{gathered}
\mathrm{CI}=\frac{\lambda_{\mathrm{MAX}}-m}{m-1}, \\
\mathrm{CR}=\frac{\mathrm{CI}}{\mathrm{RI}},
\end{gathered}
$$

where $\lambda_{\mathrm{MAX}}$ is the largest eigenvalue; $m$ the number of assessment measure; RI the random index of assessment matrix, as shown in Table IV. For our case, the CR value of 0.036 that is less than 0.1 , hence the consistency test is passed.

Step 3: determine the satisfaction probability levels of suppliers on various measures. Each supplier will be asked a question for a measure through the supplier satisfaction questionnaire. For example, "How would supplier rate yourself satisfaction with the pay on time?" Italics can

Table III.

AHP pairwise positive reciprocal comparison matrices

\begin{tabular}{llllllll}
\hline & C1 & C2 & C3 & C4 & C5 & C6 & C7 \\
\hline Green order manager (C1) & 1 & 3 & 2 & 4 & 2 & 7 & 5 \\
Green supply process (C2) & 0.33 & 1 & 0.50 & 2 & 0.33 & 3 & 2 \\
Green supplier development (C3) & 0.50 & 2 & 1 & 2 & 1 & 4 & 3 \\
Green communication (C4) & 0.25 & 0.50 & 0.50 & 1 & 0.50 & 2 & 2 \\
Green cooperation (C5) & 0.50 & 3 & 1 & 2 & 1 & 3 & 2 \\
Green conflict management (C6) & 0.14 & 0.33 & 0.25 & 0.50 & 0.33 & 1 & 2 \\
Green commitment (C7) & 0.20 & 0.50 & 0.33 & 0.50 & 0.50 & 0.50 & 1 \\
\hline
\end{tabular}

Table IV.

\begin{tabular}{lcccccccccr}
\hline Size of matrix & 1 & 2 & 3 & 4 & 5 & 6 & 7 & 8 & 9 & 10 \\
\hline Random consistency & 0 & 0 & 0.58 & 0.9 & 1.12 & 1.24 & 1.32 & 1.41 & 1.45 & 1.49 \\
\hline
\end{tabular}


be replaced by other green satisfaction measures. The decision makers of each supplier need to identify probability values of itself on each of the green satisfaction measures. The decision makers assign textual perceptual scores ranging from very low probability to very high probability for each supplier and their measures. The seven level scale used in this study is shown in Table V. Then, each supplier $(i)$ has identified a score $v_{i j}$ for each measure $(j)$ for each respective scale level.

The textual assignments for our case example are shown in Table VI. In this step, we ask the 30 suppliers to self-evaluate the probability values of seven green satisfaction measures.

Step 4: acquire the subjective weight of each measure by IET. We complete this step by using Equations (1)-(3) and get the subjective weight of each satisfaction attribute. For our case, we obtain the subjective weights $w_{j}^{s}: 0.134,0.135,0.147,0.142,0.150,0.159,0.133$.

\begin{tabular}{|c|c|c|}
\hline Scale & $v(\%)$ & \\
\hline Very low probability (VL) & 10 & \\
\hline Low probability $(\mathrm{L})$ & 30 & \\
\hline Moderate low probability (ML) & 40 & \\
\hline Moderate probability (M) & 50 & \\
\hline Moderate high probability (MH) & 60 & \\
\hline High probability $(\mathrm{H})$ & 80 & Table V. \\
\hline Very high probability (VH) & 100 & Scale of attribute level \\
\hline
\end{tabular}

\begin{tabular}{|c|c|c|c|c|c|c|c|c|}
\hline Supplier & $\mathrm{C} 1$ & $\mathrm{C} 2$ & C3 & $\mathrm{C} 4$ & C5 & $\mathrm{C} 6$ & $\mathrm{C} 7$ & \\
\hline Supplier 1 & $\mathrm{H}$ & MH & ML & MH & MH & $\mathrm{L}$ & ML & \\
\hline Supplier 2 & ML & $\mathrm{VL}$ & $\mathrm{H}$ & $\mathrm{VL}$ & ML & $\mathrm{VH}$ & $\mathrm{MH}$ & \\
\hline Supplier 3 & $\mathrm{H}$ & VH & ML & $\mathrm{H}$ & $\mathrm{H}$ & $\mathrm{H}$ & $\mathrm{ML}$ & \\
\hline Supplier 4 & $\mathrm{VH}$ & $\mathrm{H}$ & $\mathrm{L}$ & $\mathrm{H}$ & MH & $\mathrm{H}$ & $\mathrm{H}$ & \\
\hline Supplier 5 & $\mathrm{H}$ & VH & $\mathrm{H}$ & $\mathrm{L}$ & $\mathrm{H}$ & $\mathrm{H}$ & $\mathrm{L}$ & \\
\hline Supplier 6 & $\mathrm{VH}$ & $\mathrm{MH}$ & $\mathrm{VL}$ & $\mathrm{H}$ & MH & $\mathrm{MH}$ & VH & \\
\hline Supplier 7 & MH & $\mathrm{M}$ & $\mathrm{M}$ & $\mathrm{VL}$ & $\mathrm{VL}$ & $\mathrm{H}$ & $\mathrm{H}$ & \\
\hline Supplier 8 & $\mathrm{~L}$ & $\mathrm{H}$ & $\mathrm{M}$ & $\mathrm{L}$ & $\mathrm{L}$ & $\mathrm{H}$ & VH & \\
\hline Supplier 9 & $\mathrm{~L}$ & $\mathrm{VL}$ & VL & $\mathrm{VL}$ & $\mathrm{L}$ & $\mathrm{H}$ & $\mathrm{L}$ & \\
\hline Supplier 10 & $\mathrm{H}$ & $\mathrm{L}$ & VL & $\mathrm{VL}$ & $\mathrm{H}$ & $\mathrm{H}$ & $\mathrm{L}$ & \\
\hline Supplier 11 & VL & $\mathrm{H}$ & $\mathrm{H}$ & $\mathrm{ML}$ & $\mathrm{H}$ & VL & VL & \\
\hline Supplier 12 & $\mathrm{H}$ & $\mathrm{H}$ & $\mathrm{H}$ & $\mathrm{H}$ & MH & $\mathrm{H}$ & $\mathrm{H}$ & \\
\hline Supplier 13 & $\mathrm{~L}$ & $\mathrm{H}$ & $\mathrm{VL}$ & $\mathrm{L}$ & $\mathrm{H}$ & $\mathrm{L}$ & VL & \\
\hline Supplier 14 & $\mathrm{~L}$ & $\mathrm{~L}$ & $\mathrm{H}$ & MH & $\mathrm{ML}$ & $\mathrm{H}$ & M & \\
\hline Supplier 15 & $\mathrm{M}$ & MH & $\mathrm{L}$ & $\mathrm{L}$ & $\mathrm{L}$ & VH & $\mathrm{L}$ & \\
\hline Supplier 16 & $\mathrm{~L}$ & $\mathrm{M}$ & $\mathrm{M}$ & $\mathrm{M}$ & $\mathrm{L}$ & $\mathrm{L}$ & $\mathrm{L}$ & \\
\hline Supplier 17 & $\mathrm{H}$ & MH & ML & MH & MH & $\mathrm{L}$ & $\mathrm{ML}$ & \\
\hline Supplier 18 & $\mathrm{H}$ & M & ML & $\mathrm{L}$ & $\mathrm{H}$ & $\mathrm{L}$ & $\mathrm{VH}$ & \\
\hline Supplier 19 & M & $\mathrm{H}$ & $\mathrm{MH}$ & $\mathrm{H}$ & ML & VL & $\mathrm{ML}$ & \\
\hline Supplier 20 & $\mathrm{H}$ & MH & ML & MH & $\mathrm{MH}$ & $\mathrm{L}$ & $\mathrm{ML}$ & \\
\hline Supplier 21 & VL & $\mathrm{H}$ & $\mathrm{H}$ & $\mathrm{L}$ & $\mathrm{H}$ & $\mathrm{L}$ & VL & \\
\hline Supplier 22 & MH & $\mathrm{VL}$ & $\mathrm{L}$ & $\mathrm{VL}$ & $\mathrm{H}$ & $\mathrm{H}$ & $\mathrm{MH}$ & \\
\hline Supplier 23 & $\mathrm{H}$ & $\mathrm{M}$ & $\mathrm{ML}$ & L & $\mathrm{H}$ & $\mathrm{L}$ & $\mathrm{H}$ & \\
\hline Supplier 24 & VL & $\mathrm{M}$ & $\mathrm{L}$ & $\mathrm{VH}$ & MH & $\mathrm{L}$ & $\mathrm{H}$ & \\
\hline Supplier 25 & $\mathrm{VH}$ & $\mathrm{ML}$ & $\mathrm{M}$ & MH & $\mathrm{MH}$ & MH & $\mathrm{L}$ & \\
\hline Supplier 26 & $\mathrm{~L}$ & $\mathrm{~L}$ & $\mathrm{~L}$ & $\mathrm{H}$ & $\mathrm{M}$ & $\mathrm{H}$ & $\mathrm{H}$ & \\
\hline Supplier 27 & $\mathrm{~L}$ & $\mathrm{~L}$ & $\mathrm{H}$ & $\mathrm{L}$ & $\mathrm{H}$ & $\mathrm{H}$ & $\mathrm{H}$ & Table VI. \\
\hline Supplier 28 & $\mathrm{H}$ & $\mathrm{M}$ & ML & $\mathrm{L}$ & $\mathrm{H}$ & $\mathrm{L}$ & $\mathrm{H}$ & Self-evaluation of \\
\hline Supplier 29 & MH & $\mathrm{L}$ & $\mathrm{H}$ & $\mathrm{L}$ & M & $\mathrm{L}$ & VL & suppliers on \\
\hline Supplier 30 & $\mathrm{ML}$ & $\mathrm{H}$ & $\mathrm{L}$ & ML & $\mathrm{L}$ & $\mathrm{MH}$ & $\mathrm{MH}$ & satisfaction measures \\
\hline
\end{tabular}


MSCRA

2,2

74

Step 5: determine the overall final measure weight level by adjusting for double weight importance. We first determine the adjusted measure importance weight for each measure $j$ with objective weight $\left(w_{j}^{o}\right)$ and subjective weight $\left(w_{j}^{s}\right)$. We do this using the following equation:

$$
\tilde{w}_{j}=\alpha w_{j}^{o}+\beta w_{j}^{s},
$$

where $0 \leqslant \alpha \leqslant 1$ is the importance level of the objective weight, $0 \leqslant \beta \leqslant 1$ is the importance level of subjective weight, where $\alpha+\beta=1$. For our case, we set the same value for the degree $\alpha$ of objective weight and for the degree $\beta$ of subjective weight, i.e. $\alpha=\beta=0.5$. The final measure weight values obtained are: $0.235,0.123,0.165,0.114,0.163,0.106,0.093$.

Step 6: determine the normalized adjusted satisfaction levels of suppliers for each measure. In this step, we seek to adjust the measure double weight levels determined in Step 5 by adjusting these levels for each supplier $i\left(v_{i j}\right)$ with adjusted measure $j$ importance weighting $\left(\tilde{w}_{j}\right)$. The adjusted aggregated measure weight scores $\tilde{v}_{i j}$ are derived from the following equation:

$$
\tilde{v}_{i j}=\tilde{w}_{j} \times v_{i j} \quad \forall i \in n \text {. }
$$

The normalized value $n_{i j}$ is calculated as:

$$
x_{i j}=\tilde{v}_{i j} / \sqrt{\sum_{i=1}^{n} \tilde{v}_{i j}^{2}}, \quad j=1, \ldots, m, \quad i=1, \ldots, n .
$$

For our case, the overall normalized adjusted measure levels for each supplier is presented in Table VII.

Step 7: determine the most satisfied supplier(s). We determine the positive ideal and negative ideal supplier:

$$
\begin{aligned}
& \bar{x}=\left\{\left(\max _{1 \leqslant j \leqslant m} x_{i j} \mid j \in J\right), \quad\left(\min _{1 \leqslant j \leqslant m} x_{i j} \mid j \in I\right) \mid i=1, \ldots, n\right\}, \\
& \underline{x}=\left\{\left(\min _{1 \leqslant j \leqslant m} x_{i j} \mid j \in I\right), \quad\left(\max _{1 \leqslant j \leqslant m} x_{i j} \mid j \in J\right) \mid i=1, \ldots, n\right\},
\end{aligned}
$$

where $I$ is associated with benefit criteria, and $J$ is associated with cost criteria. We calculate the separation from the ideal solution using the symmetrizing KL distances. The separation of each supplier from the ideal solution is given as:

$$
\bar{S}_{i}=\sum_{i=1}^{n}\left\{\bar{x}_{i} \log \frac{\bar{x}_{i}}{x_{i}}+x_{i} \log \frac{x_{i}}{\bar{x}}\right\} .
$$

Similarly, the separation from the negative ideal solution is given as:

$$
\underline{S}_{i}=\sum_{i=1}^{n}\left\{\underline{x}_{i} \log \frac{x_{i}}{x_{i}}+x_{i} \log \frac{x_{i}}{\underline{x}_{i}}\right\} .
$$

Then, the relative closeness to the ideal solution needs to be calculated. The relative closeness of the alternative $R_{i}$ with respect to $\bar{x}$ is defined as:

$$
R_{j}=\underline{S_{i}} /\left(\overline{S_{i}}+\underline{S_{i}}\right), i=1, \ldots, n .
$$

Since $S_{j} \geqslant 0$ and $\overline{S_{j}} \geqslant 0$, then, clearly, $R_{j} \in[0,1]$. 


\begin{tabular}{|c|c|c|c|c|c|c|c|c|}
\hline Supplier & $\mathrm{C} 1$ & $\mathrm{C} 2$ & C3 & $\mathrm{C} 4$ & $\mathrm{C} 5$ & $\mathrm{C} 6$ & $\mathrm{C} 7$ & $\begin{array}{l}\text { Evaluating } \\
\text { oreen sunnlier }\end{array}$ \\
\hline Supplier 1 & 0.044 & 0.013 & 0.009 & 0.014 & 0.017 & 0.003 & 0.005 & {$[\mathrm{DO}$} \\
\hline Supplier 2 & 0.011 & 0.000 & 0.037 & 0.000 & 0.008 & 0.031 & 0.010 & \\
\hline Supplier 3 & 0.044 & 0.037 & 0.009 & 0.026 & 0.031 & 0.020 & 0.005 & \\
\hline Supplier 4 & 0.068 & 0.024 & 0.005 & 0.026 & 0.017 & 0.020 & 0.018 & \\
\hline Supplier 5 & 0.044 & 0.037 & 0.037 & 0.004 & 0.031 & 0.020 & 0.003 & \\
\hline Supplier 6 & 0.068 & 0.013 & 0.001 & 0.026 & 0.017 & 0.011 & 0.028 & 75 \\
\hline Supplier 7 & 0.024 & 0.009 & 0.014 & 0.000 & 0.000 & 0.020 & 0.018 & \\
\hline Supplier 8 & 0.006 & 0.024 & 0.014 & 0.004 & 0.004 & 0.020 & 0.028 & \\
\hline Supplier 9 & 0.006 & 0.000 & 0.001 & 0.000 & 0.004 & 0.020 & 0.003 & \\
\hline Supplier 10 & 0.044 & 0.003 & 0.001 & 0.000 & 0.031 & 0.020 & 0.003 & \\
\hline Supplier 11 & 0.001 & 0.024 & 0.037 & 0.006 & 0.031 & 0.000 & 0.000 & \\
\hline Supplier 12 & 0.044 & 0.024 & 0.037 & 0.026 & 0.017 & 0.020 & 0.018 & \\
\hline Supplier 13 & 0.006 & 0.024 & 0.001 & 0.004 & 0.031 & 0.003 & 0.000 & \\
\hline Supplier 14 & 0.006 & 0.003 & 0.037 & 0.014 & 0.008 & 0.020 & 0.007 & \\
\hline Supplier 15 & 0.017 & 0.013 & 0.005 & 0.004 & 0.004 & 0.031 & 0.003 & \\
\hline Supplier 16 & 0.006 & 0.009 & 0.014 & 0.010 & 0.004 & 0.003 & 0.003 & \\
\hline Supplier 17 & 0.044 & 0.013 & 0.009 & 0.014 & 0.017 & 0.003 & 0.005 & \\
\hline Supplier 18 & 0.044 & 0.009 & 0.009 & 0.004 & 0.031 & 0.003 & 0.028 & \\
\hline Supplier 19 & 0.017 & 0.024 & 0.021 & 0.026 & 0.008 & 0.000 & 0.005 & \\
\hline Supplier 20 & 0.044 & 0.013 & 0.009 & 0.014 & 0.017 & 0.003 & 0.005 & \\
\hline Supplier 21 & 0.001 & 0.024 & 0.037 & 0.004 & 0.031 & 0.003 & 0.000 & \\
\hline Supplier 22 & 0.024 & 0.000 & 0.005 & 0.000 & 0.031 & 0.020 & 0.010 & \\
\hline Supplier 23 & 0.044 & 0.009 & 0.009 & 0.004 & 0.031 & 0.003 & 0.018 & \\
\hline Supplier 24 & 0.001 & 0.009 & 0.005 & 0.040 & 0.017 & 0.003 & 0.018 & \\
\hline Supplier 25 & 0.068 & 0.006 & 0.014 & 0.014 & 0.017 & 0.011 & 0.003 & \\
\hline Supplier 26 & 0.006 & 0.003 & 0.005 & 0.026 & 0.012 & 0.020 & 0.018 & \\
\hline Supplier 27 & 0.006 & 0.003 & 0.037 & 0.004 & 0.031 & 0.020 & 0.018 & \\
\hline Supplier 28 & 0.044 & 0.009 & 0.009 & 0.004 & 0.031 & 0.003 & 0.018 & Table VII. \\
\hline Supplier 29 & 0.024 & 0.003 & 0.037 & 0.004 & 0.012 & 0.003 & 0.000 & The overall \\
\hline Supplier 30 & 0.011 & 0.024 & 0.005 & 0.006 & 0.004 & 0.011 & 0.010 & normalized adjusted \\
\hline Ideal supplier & 0.068 & 0.037 & 0.037 & 0.040 & 0.031 & 0.031 & 0.028 & measure levels for \\
\hline Negative ideal supplier & 0.001 & 0.000 & 0.001 & 0.000 & 0.000 & 0.000 & 0.000 & each supplier \\
\hline
\end{tabular}

The relative closeness values for each supplier for our case are provided in Table VIII. The results show that the Supplier $12\left(S_{12}\right)$ is the most satisfied supplier with a score of 0.948 . The next two most satisfied suppliers are Supplier $4\left(S_{4}\right)$ and Supplier $3\left(S_{3}\right)$ with satisfaction scores of 0.885 and 0.854 , respectively.

\subsection{Managerial implications}

The methodology presented provides the management with information regarding those suppliers that are satisfied and those that are not in the green cooperation process.

Satisfactory supplier set. From the relative closeness values, it is easy for a buyer to identify which suppliers are satisfied. The buyer can continue to cooperate with these green suppliers. The buyer can consider further strengthening cooperation with these suppliers. Buyers can also analyze why these suppliers are satisfied and use this evidence to improve the satisfaction levels of those not-satisfied suppliers.

Unsatisfactory supplier set. Using the relative closeness values, the lowest 10 suppliers can be perceived as the final set of not-satisfied suppliers from among the 30 suppliers in the original set. The buyer can then focus on taking major initiatives to improve these suppliers' sense of fairness as to buyer company's level of cooperation. If the buyer does not have enough resources to start such initiatives, one other option could be dropping the non-critical suppliers among the not-satisfied suppliers. However, such an exclusion may require further evaluation of the impact of dropping these suppliers. 


\begin{tabular}{|c|c|c|c|c|c|c|c|c|c|c|c|c|}
\hline \multirow[t]{5}{*}{2,2} & $\begin{array}{l}\alpha \\
\zeta\end{array}$ & $\begin{array}{c}0 \\
1.0\end{array}$ & $\begin{array}{l}0.1 \\
0.9\end{array}$ & $\begin{array}{l}0.2 \\
0.8\end{array}$ & $\begin{array}{l}0.3 \\
0.7\end{array}$ & $\begin{array}{l}0.4 \\
0.6\end{array}$ & $\begin{array}{l}0.5 \\
0.5\end{array}$ & $\begin{array}{l}0.6 \\
0.4\end{array}$ & $\begin{array}{l}0.7 \\
0.3\end{array}$ & $\begin{array}{l}0.8 \\
0.2\end{array}$ & $\begin{array}{l}0.9 \\
0.1\end{array}$ & $\begin{array}{c}1.0 \\
0\end{array}$ \\
\hline & Supplier 1 & 0.540 & 0.558 & 0.577 & 0.596 & 0.614 & 0.633 & 0.651 & 0.669 & 0.687 & 0.705 & 0.723 \\
\hline & Supplier 2 & 0.450 & 0.445 & 0.441 & 0.436 & 0.431 & 0.426 & 0.421 & 0.416 & 0.410 & 0.405 & 0.399 \\
\hline & Supplier 3 & 0.854 & 0.857 & 0.860 & 0.863 & 0.866 & 0.869 & 0.872 & 0.876 & 0.879 & 0.882 & 0.885 \\
\hline & Supplier 4 & 0.885 & 0.886 & 0.887 & 0.888 & 0.888 & 0.889 & 0.890 & 0.890 & 0.891 & 0.892 & 0.892 \\
\hline \multirow[t]{21}{*}{76} & Supplier 5 & 0.762 & 0.772 & 0.782 & 0.792 & 0.802 & 0.813 & 0.823 & 0.833 & 0.843 & 0.853 & 0.864 \\
\hline & Supplier 6 & 0.760 & 0.761 & 0.763 & 0.764 & 0.765 & 0.767 & 0.768 & 0.769 & 0.770 & 0.771 & 0.772 \\
\hline & Supplier 7 & 0.439 & 0.436 & 0.434 & 0.431 & 0.429 & 0.426 & 0.423 & 0.420 & 0.417 & 0.414 & 0.411 \\
\hline & Supplier 8 & 0.634 & 0.616 & 0.598 & 0.580 & 0.561 & 0.541 & 0.521 & 0.500 & 0.479 & 0.457 & 0.434 \\
\hline & Supplier 9 & 0.156 & 0.149 & 0.142 & 0.135 & 0.128 & 0.121 & 0.114 & 0.107 & 0.099 & 0.091 & 0.083 \\
\hline & Supplier 10 & 0.390 & 0.401 & 0.413 & 0.424 & 0.435 & 0.447 & 0.458 & 0.470 & 0.481 & 0.493 & 0.505 \\
\hline & Supplier 11 & 0.367 & 0.369 & 0.371 & 0.373 & 0.375 & 0.377 & 0.379 & 0.381 & 0.383 & 0.385 & 0.387 \\
\hline & Supplier 12 & 0.948 & 0.948 & 0.948 & 0.948 & 0.948 & 0.948 & 0.949 & 0.949 & 0.949 & 0.949 & 0.949 \\
\hline & Supplier 13 & 0.285 & 0.287 & 0.289 & 0.291 & 0.293 & 0.296 & 0.298 & 0.300 & 0.303 & 0.305 & 0.307 \\
\hline & Supplier 14 & 0.572 & 0.561 & 0.550 & 0.538 & 0.527 & 0.515 & 0.504 & 0.492 & 0.481 & 0.469 & 0.458 \\
\hline & Supplier 15 & 0.469 & 0.461 & 0.454 & 0.446 & 0.438 & 0.429 & 0.420 & 0.411 & 0.402 & 0.391 & 0.381 \\
\hline & Supplier 16 & 0.242 & 0.242 & 0.241 & 0.240 & 0.239 & 0.238 & 0.237 & 0.236 & 0.235 & 0.234 & 0.233 \\
\hline & Supplier 17 & 0.540 & 0.558 & 0.577 & 0.596 & 0.614 & 0.633 & 0.651 & 0.669 & 0.687 & 0.705 & 0.723 \\
\hline & Supplier 18 & 0.617 & 0.628 & 0.639 & 0.650 & 0.661 & 0.673 & 0.684 & 0.696 & 0.708 & 0.720 & 0.732 \\
\hline & Supplier 19 & 0.500 & 0.507 & 0.514 & 0.522 & 0.529 & 0.537 & 0.545 & 0.554 & 0.563 & 0.572 & 0.582 \\
\hline & Supplier 20 & 0.540 & 0.558 & 0.577 & 0.596 & 0.614 & 0.633 & 0.651 & 0.669 & 0.687 & 0.705 & 0.723 \\
\hline & Supplier 21 & 0.394 & 0.394 & 0.393 & 0.393 & 0.393 & 0.392 & 0.392 & 0.392 & 0.391 & 0.391 & 0.391 \\
\hline & Supplier 22 & 0.397 & 0.400 & 0.403 & 0.407 & 0.410 & 0.413 & 0.417 & 0.421 & 0.424 & 0.428 & 0.432 \\
\hline & Supplier 23 & 0.568 & 0.583 & 0.598 & 0.613 & 0.627 & 0.642 & 0.657 & 0.672 & 0.687 & 0.702 & 0.717 \\
\hline & Supplier 24 & 0.529 & 0.507 & 0.486 & 0.465 & 0.444 & 0.424 & 0.404 & 0.384 & 0.364 & 0.345 & 0.325 \\
\hline & Supplier 25 & 0.634 & 0.655 & 0.675 & 0.694 & 0.712 & 0.730 & 0.747 & 0.764 & 0.780 & 0.795 & 0.810 \\
\hline \multirow{5}{*}{$\begin{array}{l}\text { Table VIII. } \\
\text { Relative closeness } \\
\text { values for each } \\
\text { supplier by adjusting } \\
\text { the } \alpha \text { and } \beta(\alpha+\beta=1)\end{array}$} & Supplier 26 & 0.608 & 0.587 & 0.566 & 0.544 & 0.522 & 0.500 & 0.477 & 0.454 & 0.430 & 0.406 & 0.381 \\
\hline & Supplier 27 & 0.629 & 0.620 & 0.611 & 0.602 & 0.593 & 0.584 & 0.575 & 0.566 & 0.557 & 0.547 & 0.538 \\
\hline & Supplier 28 & 0.568 & 0.583 & 0.598 & 0.613 & 0.627 & 0.642 & 0.657 & 0.672 & 0.687 & 0.702 & 0.717 \\
\hline & Supplier 29 & 0.315 & 0.333 & 0.351 & 0.369 & 0.388 & 0.407 & 0.427 & 0.447 & 0.468 & 0.489 & 0.511 \\
\hline & Supplier 30 & 0.470 & 0.460 & 0.450 & 0.440 & 0.429 & 0.419 & 0.408 & 0.397 & 0.387 & 0.376 & 0.365 \\
\hline
\end{tabular}

This paper also has other managerial implications which have not been fully investigated in the literature. First, we incorporate various measures from environmental perspective to evaluate green supplier satisfaction. The methodology presented not only can help the buyer to evaluate the existing satisfaction degree of the supplier based on the defined measures, but also sheds light on ways to improve green supplier satisfaction. Such a framework strengthens the theoretical foundation for green supplier satisfaction through the processes of evaluation and improvement. Second, the green supplier satisfaction evaluation has the potential of being the base of green supplier management. It can help the buyer to identify potential cooperation risks in advance. Hence, the buyer not only needs to identify the satisfactory supplier set, but also has to identify the not-satisfied supplier set.

\section{Sensitivity analysis}

To determine the robustness of this relationship and ranking of suppliers, a sensitivity analysis is conducted. For the illustrative case, $\alpha=\beta=0.5$, relationship is assumed for the objective weight $\left(w_{j}^{o}\right)$ and the subjective weight $\left(w_{j}^{s}\right)$ for measures. A symmetrize KL distance is used to improve the TOPSIS method.

\subsection{Varying parameters $\alpha$ and $\beta$}

Let $\alpha+\beta=1$ remain fixed and $\alpha$ is varied over the range $0 \leqslant \xi \leqslant 1.0$, in increments of 0.1 . The new relative closeness value of suppliers when the parameter value $\alpha$ is increased 
is shown in Table IX. The ranks of the Top 4 and the Last 3 suppliers have not changed. Interestingly, other 23 suppliers change position over these relative closeness values. These results are due to the subjective weight $\left(w_{i}^{s}\right)$ being greater than the objective weight $\left(w_{j}^{o}\right)$ among suppliers. This shows the sensitivity of green supplier satisfaction to the choice of weights. Hence, the buyers need to pay attention to the process of weight determination. This is why we use the two methods, AHP- and IET-based weights, to make the determination of subjective and objective weights more structured and scientific.

\subsection{Entropy-TOPSIS vs TOPSIS method}

The entropy-TOPSIS method uses the symmetrize KL distance to measure the difference in the probability distributions of green supplier satisfaction, whereas the traditional TOPSIS method does not. The rankings for 63 percent of suppliers are changed, by the use of one method vs the other, as illustrated in Table IX. The important point to note is that the traditional TOPSIS method, which does not take into consideration the probability distributions of green supplier satisfaction, cannot provide decision makers with more reference information in supplier satisfaction evaluation compared to that provided by the entropy-TOPSIS method.

\section{Concluding remarks, limitations and areas for future research}

The main contributions of this paper are threefold. First, this paper highlights the concept of green supplier satisfaction and clarifies its importance in GSCM. Today's green supply

\begin{tabular}{|c|c|c|c|c|}
\hline Method & Entropy-TOPSIS & Ranks & TOPSIS & Ranks \\
\hline Supplier 1 & 0.633 & 10 & 0.442 & 10 \\
\hline Supplier 2 & 0.426 & 20 & 0.374 & 18 \\
\hline Supplier 3 & 0.869 & 3 & 0.603 & 4 \\
\hline Supplier 4 & 0.889 & 2 & 0.658 & 2 \\
\hline Supplier 5 & 0.813 & 4 & 0.594 & 5 \\
\hline Supplier 6 & 0.767 & 5 & 0.610 & 3 \\
\hline Supplier 7 & 0.426 & 21 & 0.338 & 24 \\
\hline Supplier 8 & 0.541 & 14 & 0.351 & 23 \\
\hline Supplier 9 & 0.121 & 30 & 0.175 & 30 \\
\hline Supplier 10 & 0.447 & 18 & 0.433 & 13 \\
\hline Supplier 11 & 0.377 & 27 & 0.380 & 15 \\
\hline Supplier 12 & 0.948 & 1 & 0.661 & 1 \\
\hline Supplier 13 & 0.296 & 28 & 0.300 & 27 \\
\hline Supplier 14 & 0.515 & 16 & 0.355 & 22 \\
\hline Supplier 15 & 0.429 & 19 & 0.312 & 26 \\
\hline Supplier 16 & 0.238 & 29 & 0.185 & 29 \\
\hline Supplier 17 & 0.633 & 11 & 0.442 & 11 \\
\hline Supplier 18 & 0.673 & 7 & 0.484 & 7 \\
\hline Supplier 19 & 0.537 & 15 & 0.376 & 17 \\
\hline Supplier 20 & 0.633 & 12 & 0.442 & 12 \\
\hline Supplier 21 & 0.392 & 26 & 0.378 & 16 \\
\hline Supplier 22 & 0.413 & 24 & 0.361 & 20 \\
\hline Supplier 23 & 0.642 & 8 & 0.464 & 8 \\
\hline Supplier 24 & 0.424 & 22 & 0.357 & 21 \\
\hline Supplier 25 & 0.730 & 6 & 0.558 & 6 \\
\hline Supplier 26 & 0.500 & 17 & 0.322 & 25 \\
\hline Supplier 27 & 0.584 & 13 & 0.405 & 14 \\
\hline Supplier 28 & 0.642 & 9 & 0.464 & 9 \\
\hline Supplier 29 & 0.407 & 25 & 0.364 & 19 \\
\hline Supplier 30 & 0.419 & 23 & 0.267 & 28 \\
\hline
\end{tabular}

\section{Evaluating green supplier satisfaction}


MSCRA

2,2

78

chain's effectiveness largely depends upon the integration and satisfaction of suppliers. The results of the green supplier satisfaction evaluation help the buyer understand the nature and quality of the relationships with the suppliers. Hence, it serves as a starting point for the buyer's adjustments to supplier concerns. The green supplier satisfaction evaluation also provides the buyer with a tool to guide and plan the GSCM practices.

Second, this paper develops an effective framework for green supplier satisfaction, incorporating various measures from environmental perspectives. We focus on the integration of green satisfaction measures and attributes based on the literature. The number and type of measures provide evidence of the complex nature of satisfaction decisions and how techniques to manage these measures and their application to supplier satisfaction evaluations set the stage for the methodology proposed in this paper. These measures not only can be used to evaluate the level of green supplier satisfaction, but also provide the buyers a reference as to how to improve their suppliers' satisfaction. The supplier satisfaction index (SSI) also assists the buyers in identifying the areas that need further improvement with the suppliers, as the SSI is an index that provides information on how well the suppliers are satisfied on different activities of the buyers throughout the entire process of purchasing.

Third, in this paper, we introduced a multi-step, multi-method approach to help evaluate the green supplier satisfaction decision with the use of using multiple factors. The methodology developed integrates AHP and IET and entropy-TOPSIS methods into a seven step decision support process. It also helps in the ranking and further identification of a satisfied or unsatisfied supplier. The application to green supplier satisfaction evaluation and decision making is made possible through the use of objective weights and subjective weights. Buyers can further refine their decision making quality to maintain some consistency with further weighting of measures that are salient for the buyer's strategic direction. Our approach contributes to this process.

The framework and the tool of the green supplier satisfaction evaluation are not ends in themselves; rather, they offer buyers a steering model and tool to avoid possible negative repercussions resulting from green supplier dissatisfaction. For instance, an unsatisfied supplier may produce poor green quality output that lowers the green degree of a buyer's products and thus influences the buyer's sale volumes and profitability. Thus, not only the link between green supplier satisfaction and value creation but also the reciprocity between green supplier satisfaction and green supplier management are evident.

Like in any other study, there are limitations involved in our work which provide avenues for future research. One of the main limitations is that the illustrative example introduced is a conceptual one. A real-world application needs to be investigated to validate the operational feasibility of the methodology developed. However, the difficulties associated with accessing real life data may prove to be a major hindrance in this regard. Another limitation is that many social responsibility issues such as employment safety, women's rights, community participation are not included in the framework used. Green supplier satisfaction as it is linked to green supply chain performance can also be another area of research. By the same token, the impact of green supplier satisfaction on the buyer's green purchasing policy and practices can also be studied.

\section{References}

Alegre, I., Mas-Machuca, M. and Berbegal-Mirabent, J. (2016), "Antecedents of employee job satisfaction: do they matter?”, Journal of Business Research, Vol. 69 No. 4, pp. 1390-1395.

Anderson, J.C. and Narus, J.A. (1984), "A model of the distributor's perspective of distributor-manufacturer working relationships", Journal of Marketing, Vol. 48 No. 4, pp. $62-74$. 
Bai, C. and Sarkis, J. (2010), "Green supplier development: analytical evaluation using rough set theory", Journal of Cleaner Production, Vol. 18 No. 12, pp. 1200-1210.

Bai, C. and Sarkis, J. (2013), "Green information technology strategic justification and evaluation", Information Systems Frontiers, Vol. 15 No. 5, pp. 831-847.

Bai, C. and Sarkis, J. (2014), "Determining and applying sustainable supplier key performance indicators", Supply Chain Management: An International Journal, Vol. 19 No. 3, pp. 275-291.

Bai, C. and Sarkis, J. (2019), "Integrating and extending data and decision tools for sustainable third-party reverse logistics provider selection", Computers \& Operations Research, Vol. 110, pp. 188-207.

Bai, C. and Sarkis, J. (2018), "Integrating sustainability into supplier selection: a grey-based TOPSIS analysis", Technological and Economic Development of Economy, Vol. 24 No. 6, pp. 2202-2224.

Bai, C. and Sarkis, J. (2019), "Green supplier development: a review and analysis”, in Sarkis, J. (Ed.), Handbook on the Sustainable Supply Chain, Edward Elgar Publishing, Cheltenham, pp. 542-556.

Bai, C., Dhavale, D. and Sarkis, J. (2016), "Complex investment decisions using rough set and fuzzy c-means: an example of investment in green supply chains", European Journal of Operational Research, Vol. 248 No. 2, pp. 507-521.

Bai, C., Rezaei, J. and Sarkis, J. (2017), "Multicriteria green supplier segmentation”, IEEE Transactions on Engineering Management, Vol. 64 No. 4, pp. 515-528.

Bai, C., Kusi-Sarpong, S., Badri Ahmadi, H. and Sarkis, J. (2019), "Social sustainable supplier evaluation and selection: a group decision-support approach", International Journal of Production Research, Vol. 57 No. 22, pp. 7046-7067.

Bai, C., Shi, B., Liu, F. and Sarkis, J. (2019), "Banking credit worthiness: evaluating the complex relationships", Omega, Vol. 83, pp. 26-38.

Benton, W.C. and Maloni, M. (2005), "The influence of power driven buyer/seller relationships on supply chain satisfaction", Journal of Operations Management, Vol. 23 No. 1, pp. 1-22.

Blome, C., Hollos, D. and Paulraj, A. (2014), "Green procurement and green supplier development: antecedents and effects on supplier performance", International Journal of Production Research, Vol. 52 No. 1, pp. 32-49.

Blut, M., Frennea, C.M., Mittal, V. and Mothersbaugh, D.L. (2015), "How procedural, financial and relational switching costs affect customer satisfaction, repurchase intentions, and repurchase behavior: a meta-analysis", International Journal of Research in Marketing, Vol. 32 No. 2, pp. 226-229.

Cardozo, R.N. (1965), "An experimental study of customer effort, expectation, and satisfaction", Journal of Marketing Research, Vol. 2 No. 3, pp. 244-249.

Chen, S.J. and Hwang, C.L. (Eds) (1992), "Fuzzy multiple attribute decision making methods", Fuzzy Multiple Attribute Decision Making, Springer, Berlin and Heidelberg, pp. 289-486.

Cover, T.M. and Thomas, J.A. (2012), Elements of Information Theory, John Wiley \& Sons, Hoboken, NJ.

Davis, J.L., Green, J.D. and Reed, A. (2009), "Interdependence with the environment: commitment, interconnectedness, and environmental behavior", Journal of Environmental Psychology, Vol. 29 No. 2, pp. 173-180.

Dou, Y., Zhu, Q. and Sarkis, J. (2014), "Evaluating green supplier development programs with a greyanalytical network process-based methodology", European Journal of Operational Research, Vol. 233 No. 2, pp. 420-431.

Essig, M. and Amann, M. (2009), "Supplier satisfaction: conceptual basics and explorative findings", Journal of Purchasing and Supply Management, Vol. 15 No. 2, pp. 103-113.

Forker, L.B. and Stannack, P. (2000), "Cooperation versus competition: do buyers and suppliers really see eye-to-eye?", European Journal of Purchasing \& Supply Management, Vol. 6 No. 1, pp. 31-40.

$\mathrm{Fu}, \mathrm{X}$., Zhu, Q. and Sarkis, J. (2012), "Evaluating green supplier development programs at a telecommunications systems provider", International Journal of Production Economics, Vol. 140 No. 1, pp. 357-367. 
MSCRA

2,2

80
Ganesan, S. (1994), "Determinants of long-term orientation in buyer-seller relationships", Journal of Marketing, Vol. 58 No. 2, pp. 1-19.

Gawantka, A. (2007), “Anbieterzufriedenheit in industriellen Geschäftsbeziehungen”, Deutscher Universitäts - Verlag GWV Fachverlage, Wiesbaden, Germany.

Ghijsen, P.W., Semeijn, J. and Ernstson, S. (2010), "Supplier satisfaction and commitment: the role of influence strategies and supplier development”, Journal of Purchasing and Supply Management, Vol. 16 No. 1, pp. 17-26.

Ghosh, D. and Shah, J. (2015), "Supply chain analysis under green sensitive consumer demand and cost sharing contract”, International Journal of Production Economics, Vol. 164, pp. 319-329.

Govindan, K., Rajendran, S., Sarkis, J. and Murugesan, P. (2015), "Multi criteria decision making approaches for green supplier evaluation and selection: a literature review", Journal of Cleaner Production, Vol. 98, pp. 66-83.

Gunasekaran, A., Sharif, A.M., Zhu, Q., Dou, Y. and Sarkis, J. (2010), “A portfolio-based analysis for green supplier management using the analytical network process", Supply Chain Management: An International Journal, Vol. 15 No. 4, pp. 306-319.

Hafezalkotob, A. (2017), "Competition, cooperation, and coopetition of green supply chains under regulations on energy saving levels", Transportation Research Part E: Logistics and Transportation Review, Vol. 97, pp. 228-250.

Hollos, D., Blome, C. and Foerstl, K. (2012), "Does sustainable supplier co-operation affect performance? Examining implications for the triple bottom line”, International Journal of Production Research, Vol. 50 No. 11, pp. 2968-2986.

Johnson, D. and Sinanovic, S. (2001), "Symmetrizing the Kullback-Leibler distance", IEEE Transactions on Information Theory, Vol. 9 No. 3, pp. 96-99.

Kannan, D., de Sousa Jabbour, A.B.L. and Jabbour, C.J.C. (2014), "Selecting green suppliers based on GSCM practices: using fuzzy TOPSIS applied to a Brazilian electronics company”, European Journal of Operational Research, Vol. 233 No. 2, pp. 432-447.

Kullback, S. and Leibler, R.A. (1951), “On information and sufficiency”, The Annals of Mathematical Statistics, Vol. 22 No. 1, pp. 79-86.

Leenders, M.R., Johnson, P.F., Flynn, A.E. and Fearon, H.E. (2006), Purchasing and Supply Management with 50 Supply Chain Cases, 13th ed., McGraw-Hill, Boston, MA.

Li, W.Y., Chow, P.S., Choi, T.M. and Chan, H.L. (2016), "Supplier integration, green sustainability programs, and financial performance of fashion enterprises under global financial crisis", Journal of Cleaner Production, Vol. 135, pp. 57-70.

Maunu, S. (2003), "Supplier satisfaction: the concept and measurement system”, A study to define the supplier satisfaction elements and usage as a management tool, Department of Industrial Engineering and Management, University of Oulu, Oulu.

Meena, P.L. and Sarmah, S.P. (2012), "Development of a supplier satisfaction index model”, Industrial Management \& Data Systems, Vol. 112 No. 8, pp. 1236-1254.

Meena, P.L., Sarmah, S.P. and Sinha, S. (2012), "Measuring satisfaction in buyer-supplier relationship from suppliers perspective", International Journal of Business Performance and Supply Chain Modelling, Vol. 4 No. 1, pp. 60-74.

Mohanty, M.K. and Gahan, P. (2011a), "Supplier evaluation and selection attributes in discrete manufacturing industry-empirical study on Indian manufacturing industry", International Journal of Management Science and Engineering Management, Vol. 6 No. 6, pp. 431-441.

Mohanty, M.K. and Gahan, P. (2011b), "Small scale supplier satisfaction: an explorative finding from Indian manufacturing industry”, School of Doctoral Studies European Union, No. 3, pp. 65-76.

Praxmarer-Carus, S., Sucky, E. and Durst, S.M. (2013), "The relationship between the perceived shares of costs and earnings in supplier development programs and supplier satisfaction”, Industrial Marketing Management, Vol. 42 No. 2, pp. 202-210. 
Pulles, N.J., Schiele, H., Veldman, J. and Hüttinger, L. (2016), "The impact of customer attractiveness and supplier satisfaction on becoming a preferred customer", Industrial Marketing Management, Vol. 54, pp. 129-140.

Rashidi, K. and Saen, R.F. (2018), "Incorporating dynamic concept into gradual efficiency: improving suppliers in sustainable supplier development”, Journal of Cleaner Production, Vol. 202, pp. 226-243.

Saaty, T.L. (1990), "How to make a decision: the analytic hierarchy process", European Journal of Operational Research, Vol. 48 No. 1, pp. 9-26.

Saeidi, S.P., Sofian, S., Saeidi, P., Saeidi, S.P. and Saeidi, S.A. (2015), "How does corporate social responsibility contribute to firm financial performance? The mediating role of competitive advantage, reputation, and customer satisfaction", Journal of Business Research, Vol. 68 No. 2, pp. 341-350.

Saorín-Iborra, M.C. and Cubillo, G. (2019), "Supplier behavior and its impact on customer satisfaction: a new characterization of negotiation behavior", Journal of Purchasing and Supply Management, Vol. 25 No. 1, pp. 53-68.

Scheer, L.K. and Stern, L.W. (1992), "The effect of influence type and performance outcomes on attitude toward the influencer", Journal of Marketing Research, Vol. 29 No. 1, pp. 128-142.

Schiele, H., Calvi, R. and Gibbert, M. (2012), "Customer attractiveness, supplier satisfaction and preferred customer status: introduction, definitions and an overarching framework", Industrial Marketing Management, Vol. 41 No. 8, pp. 1178-1185.

Scholl, A., Manthey, L., Helm, R. and Steiner, M. (2005), "Solving multi-attribute design problems with analytic hierarchy process and conjoint analysis: an empirical comparison", European Journal of Operational Research, Vol. 164 No. 3, pp. 760-777.

Shannon, C.E. (1948), “A mathematical theory of communication”, Bell System Technical Journal, Vol. 27 No. 3, pp. 379-423.

Skinner, S.J., Gassenheimer, J.B. and Kelley, S.W. (1992), "Cooperation in supplier-dealer relations", Journal of Retailing, Vol. 68 No. 2, pp. 174-193.

Soetanto, R. and Proverbs, D.G. (2002), "Modelling the satisfaction of contractors: the impact of client performance", Engineering, Construction and Architectural Management, Vol. 9 Nos 5-6, pp. 453-465.

Varnäs, A., Balfors, B. and Faith-Ell, C. (2009), "Environmental consideration in procurement of construction contracts: current practice, problems and opportunities in green procurement in the Swedish construction industry", Journal of Cleaner Production, Vol. 17 No. 13, pp. 1214-1222.

Vos, F.G., Schiele, H. and Hüttinger, L. (2016), "Supplier satisfaction: explanation and out-of-sample prediction", Journal of Business Research, Vol. 69 No. 10, pp. 4613-4623.

Wong, A. (2000), "Integrating supplier satisfaction with customer satisfaction", Total Quality Management, Vol. 11 Nos 4-6, pp. 427-432.

Zhang, M., Zhao, X., Voss, C. and Zhu, G. (2016), "Innovating through services, co-creation and supplier integration: cases from China”, International Journal of Production Economics, Vol. 171, pp. 289-300.

\section{Further reading}

Saaty, T.L. (1980), The Analytical Hierarchy Process, Planning, Priority: Resource Allocation, RWS Publications, New York, NY.

\section{Corresponding author}

Chunguang Bai can be contacted at: Cbai@uestc.edu.cn

For instructions on how to order reprints of this article, please visit our website:

www.emeraldgrouppublishing.com/licensing/reprints.htm

Or contact us for further details: permissions@emeraldinsight.com 